\title{
OPPORTUNITIES AND GOOD PRACTICES FOR STRENGTHENING THE INTERGENERATIONAL LINK IN CENTRAL EUROPE - A COMPARATIVE ANALYSIS
}

\author{
Authors: \\ Anikó Varga Nagy (Ph.D.) \\ University of Debrecen (Hungary) \\ Balázs Molnár (Ph.D.) \\ University of Debrecen (Hungary) \\ E-mail address of the first author: \\ vnaniko2013@gmail.com
}

\author{
Lectors: \\ Katalin Mező (Ph.D.) \\ University of Debrecen (Hungary) \\ Ferenc Mező (Ph.D.) \\ Eszterházy Károly University (Hungary)
}

Varga Nagy, Anikó \& Molnár, Balázs (2021). Opportunities and Good Practices for Strengthening the Intergenerational Link in Central Europe - a Comparative Analysis. Különleges Bánásmód, 7. (1). 109-126. DOI 10.18458/KB.2021.1.109

\begin{abstract}
We conducted a research entitled "Learning and exchanging good practices strengthening the social role of the family" under project identification number EFOP-5.2.2.-17-2017-00048 "Research on good practices strengthening the social role of the family in the Carpathian Basin in the Hajdúsámson Reformed Parish and Family Pedagogy Association "in connection with the project. With online questionnaires we try to explore answers and solutions in research that can help professionals pass them on to families as good practice. The questions are about the family programs for different generations organized by the institution and municipality as well as the functioning of reverse socialization mechanisms in the intergenerational relationship. The aim of the paper is tp show some examples of good practices in multigenerational programs, which were examined in the research.
\end{abstract}

Keyswords: generations, strengthening the intergenerational link

Discipline: sociology

\footnotetext{
Absztrakt

GENERACIÓK KÖZÖTTI KAPCSOLAT MEGERŐSÍTÉSÉNEK LEHETŐSÉGEI ÉS JÓ GYAKORLATAI KÖZÉP-EURÓPÁBAN - ÖSSZEHASONLÍTÓ ELEMZÉS

"A család társadalmi szerepét erósitó jó gyakorlatok megismerése és cseréje" címmel végeztünk kutatást az EFOP5.2.2.-17-2017-00048 projekt azonosító számú „A család társadalmi szerepét erősítő jó gyakorlatok Kárpát-medencei kutatása a Hajdúsámsoni Református Egyházközség és a Családpedagógiai Egyesület együttmúködésében" pályázati projekthez kapcsolódóan. Online kérdőívet készítettünk a humánszolgáltatásban dolgozó szakemberek számára. A kérdőív elsősorban generációk közti kapcsolatok
} 
erősítését példázó jó gyakorlatok feltárását szolgálta, a családi közösségek összetartásának és erősitésének, valamint a mai családokat megismerő különféle lehetőségeknek a középpontba állításával. Célunk volt a több generációt megmozgató programokkal kapcsolatos jó gyakorlatok összegyújtésének a felvállalása a generációkat érintő motivációk feltárásával. Jelen tanulmányunkban az ezekkel kapcsolatos eredményeinket foglaljuk össze.

Kulcsszavak: generációk, a generációk közötti kapcsolat erősítése

Diszciplína: szociológia

\section{Theoretical background}

Over the past years, there have been several studies examining the relationship and its effectiveness between families and institution and these provide some theoretical framing for working with families in Hungary. Studies in school contexts are numerous, however, there is a paucity of research on exploring good practices that exemplify the strengthening of intergenerational relationships, focusing on the cohesion and strengthening of family communities and the various opportunities for getting to know today's families. Our goal was to undertake the collection of good practices related to multi-generational programs by exploring motivations that affect generations. Some discussion papers are available to provide examples of what might be considered as 'good practice' (Varga Nagy, 2017; 2018; 2019; 2020)

The parent's role in the child's early period of life is less of a central topic of educational policy in Hungary. It is partly because in Europe 'upbringing/care' and 'education' are considered as general social (sociological) phenomena and the less psychological. (Török, 2005) Taking the families' needs into consideration has become stronger lately. The families' inclusion into the kindergarten education materialises/happens more and more. (Korintus, 2004)

A family-friendly approach is becoming more dominant and familiar in the practice after the democratic transformation. Relationships with families have developed in their content. The family-centred view means that behind the children there is the family, and the educational plans match not only to the children but also the families' needs and their situations. (Bakonyi, 2016)

After the democratic transformation a new kind of cooperation with parents have been realized in Hungary says Korintus (Korintus, 2004). There are excellent possibilities to spend time together and to encourage relationship between families-institution, families-families and integrate children with special needs: parents' meeting before starting the kindergarten, visiting parents at their home before starting the kindergarten to raise cooperation and partnership, adopting children at the kindergarten with the help of their parents to help their transition, meeting for parents talking about children's needs of education and care to transmit the right approach for them, parents afternoon: an activity together with parents and children's siblings. Health educational programs to raise the awareness: lectures, advisement, meal exhibition. Programs, trips together with the families, garden parties in the kindergarten (baking in outside ovens etc.)

Rákó thinks, whatever the reason may be, it is the pedagogues' responsibility to find the right tone to communicate and engage with these parents and to tap into their existing skills (Rákó, 2014). ). Pedagogues' inclusive approach must ensure that they accept and value difference (unlike the socialist approach that expected everyone to be the 
same) and enable local traditions to flourish and a strong sense of belonging to develop (Varga Nagy \& Molnár, 2019). Empathy plays an important role in the relationship with the parents. The individual needs of families are gradually gaining more attention and institutions have adopted a more family-friendly approach, where not only the parents but also the whole family are invited to get involved.

Parents and pedagogues together are involved in the care and education of children and the institutions' holistic approach considers the child, first and foremost, in the context of a family. Support offered to parents is more aligned with the preferences and wishes of families and parents are no longer viewed as 'outsiders' looking in, but 'insiders' taking part in the life of a kindergarten.

\section{Research method}

The 30-question questionnaire was completed anonymously, where the person interviewed could not be identified under any circumstances. The data obtained were handled in accordance with data security regulations and processed for scientific conclusions in accordance with scientific ethical considerations.

\section{How was the questionnaire made?}

The questionnaires were distributed online to human resource professionals. In the case of online questionnaires, the efficiency of self-completion is high, and the response efficiency was increased by sending it in a targeted way to the professionals we came in contact with during the project programs. The professionals filled in the questionnaire with a high level of responsibility. The social unit examined in the projects is the family. We try to explore answers and solutions in research that can help professionals pass them on to families as good practice. By better understanding, the mapping of problems affecting the family and generations will also become more widespread.

\section{The following topics were the focus of the questionnaire}

The questionnaire consisted of three parts. After some general information, we asked a few questions about the respondents 'common family programs, and then found questions about family programs organized by their institution and municipality, as well as programs organized for generations.

- How attractive are you to the way your family members have lived, live now? We wondered if respondents would be happy to live their lives the way their parents or grandparents did, or the way their children would live.

- What of the following did you learn from your parents or grandparents? The focus on this issue is the transmission of family roles:

- baking, cooking

- household knowledge (cleaning, washing, ironing)

- love of reading

- garden care

- sewing, embroidery

- raising children

- political knowledge

- historical knowledge

For the following questions, we were interested in the functioning of reverse socialization mechanisms in the intergenerational relationship.

- What have you learned from your children?

- mobile phone usage

- appearance on a social site (eg Facebook)

- email usage 
- electronic administration (bank, mobile charging, etc.)

- getting to know interesting / useful websites

- dressing

- modern vocabulary

- political knowledge

- From the list below, what do you think you were the teacher to your parents, maybe your grandparents?

- mobile phone usage

- appearance on a social site (e.g. Facebook)

- email usage

- electronic administration (bank, mobile charging, etc.)

- getting to know interesting / useful websites

- dressing

- modern vocabulary

- political knowledge

Examples of good practices in multigenerational programs were also examined in the research.

- What joint programs does your institution organize in which several generations (eg parent-child, grandparent-child-grandchild, etc.) can participate?

- What do you experience, what are the biggest challenges in organizing multigenerational programs? Please also write about how they are trying to overcome these difficulties.

- What advice would you give to what joint programs your institution could organize for different generations?

- In addition to joint programs, what other ways and opportunities would your institution offer to reduce generational differences?

- What advice would you give on what other programs should be organized in your municipality (eg at the municipality level or even in schools) to strengthen the relationship between children-parents and grandparents?

About two-thirds of respondents reported multi-generational workplace programs, either for employees (278 people; $63.6 \%$ ) or for clients (e.g., programs involving parents and grandparents of children in educational institutions) (291 people; 66 $.6 \%)$. Of the 437 respondents, $365(83.52 \%)$ shared their experiences and thoughts. For the remaining 72 textual responses, the respondent did not experience any difficulty or could not provide a definite answer to the question, or the response did not contain evaluable information.

The length of employment had a positive effect on whether the respondent wrote good practice, suggesting that those who have worked for an institution for a longer period of time have a better view of the program offerings.

In the textual answers, the respondents named several (typical) relatively well-known, frequently used methods and programs that bring together generations. In about 10 percent of the responses, we encountered elements in programs organized for clients that, in whole or in part, seemed less known, novel, and more unusual, which we named "atypical" programs. Reviewing the responses for typical and atypical intergenerational programs, we were able to identify 18 categories into which intergenerational programs can be classified. We believe that each category has a number of specific opportunities. 
During the project, how the content of the research was formed / How good practices shaped the questions

During the project, we had the opportunity to meet a number of expert colleagues. With human service professionals who interact with families in their everyday activities. During the cooperation with them, in workshops, trainings, study trips, the main topic of the project was continuously formed. In line with the objectives of the project, we reviewed a wide range of the social role of the family with professionals and how experts who deal directly or indirectly with families can contribute to the social inclusion of families.

During the project, a comprehensive review of the Hungarian scientific literature on family-related topics was carried out. Cross-border partners were also involved in exploring the relevant literature. We also developed current and interesting questions in line with the topics in the literature.

During the workshops, the topics of conceptualization and operationalization of the Finalization of the Research Plan were also touched upon. Within the framework of the topic, we agreed on the necessary conditions for the successful and efficient conduct of the research:

- the practice of domestic and international application of the method

- characteristics of the methodology used

- background literature on the topic

- reach the target audience

- creation of an online interface for the research questionnaire

- the technique of preparing the questionnaire

- matching the type of questions in terms of efficiency and respondents

During the project, we learned a number of good practices, and not only on a theoretical basis, but also in practice. The content elements of these good practices appear in the questions: family roles, learning family patterns, reverse socialization, family leisure activities, family functions. In compiling the questionnaire, the opinions of several experts were taken into account. The questionnaire was subjected to a preliminary examination, a trial was completed, during which the questions were further shaped. Nearly half of the respondents (211 people; 48.3\%) indicated Hungary as their place of residence, followed by $103-103$ people $(23.6 \%$ - 23.6\%) Romania and Slovakia. 20 people $(4.6 \%)$ from Serbia completed the questionnaire. Respondents ranged in age from 21 to 70 years, with a mean age of 42.7 years ( $\mathrm{s}=$ 9.68) and a median of 42 years.

The majority of respondents came from smaller settlements: the village or non-major (probably smaller) city is the place of residence. we can state that with regard to educational qualifications, according to the main target group of the research (human service sector, professional field), high educational qualifications are typical. Of the 437 respondents, $370(84.7 \%)$ had at least a degree in higher education ( 3 of them had a doctorate) and only 7 had not completed their secondary school diploma. Due to the peculiarities of the field of human services, higher education degrees dominated.

\section{The Research}

Between 14 April and 8 July 2020, 437 people completed the 30-question survey created by the Google Forms application, which was distributed in Hungarian in four countries (Hungary, Romania, Serbia, Slovakia), targeting mainly those working in the human services sector. . Due to the peculiarities of the online questionnaire, employees from other spheres could also express their opinions and experiences, but the vast majority of respondents could be classified in this professional field, for example, working in the social, pedagogical or health fields. 
The questionnaire was primarily designed to explore good practices that exemplify the strengthening of intergenerational relationships, focusing on the cohesion and strengthening of family communities and the various opportunities for getting to know today's families. Our goal was to create a collection of good practices related to multi-generational programs by exploring motivations that affect generations. In the present study, we summarize our findings in relation to these. The social unit examined in the project is the family. Families have been affected greatly by the social and economic changes of the 21st century, yet there has never been a greater need for family unity. In our research, we try to explore answers and solutions that can help professionals pass them on to families as good practice. In the course of the research, our goal was to find good practices that help to expand the complex possibilities of getting to know the family for family professionals. Through better knowledge, the mapping of problems affecting the family and generations will also become more widespread, so, as well as by sharing the good practices identified in the research, we might have more tools to deal with problems affecting families.

Our long-term goal is to enable professional organizations to work more effectively by sharing the experiences from the research through the sharing of experiences that we gained. We try to equip the professionals with the skills we have experienced during the research, and the knowledge thus accumulated can be a starting point for family professionals to adapt the model they think is feasible for them.

We recommend research to all institutions in which social community building is considered important, they strengthen human relations by organizing joint programs, preparing together, taking joint action, paying attention to each other, and experiencing the community experience together, thus consolidating the cooperation between the family and the specific institutions.

It is recommended for all families, as well as for family professionals who share the results with families. In addition to the role of the family, the tasks and responsibilities of the institutions are also decisive, so the knowledge gained should be passed on to professionals who have direct contact with families.

\section{Sociodemographic characteristics of respondents}

Nearly half of the respondents (211 people; $48.3 \%$ ) indicated Hungary as their place of residence (Table 1), followed by 103-103 people $(23.6 \%-23.6 \%)$ Romania and Slovakia. 20 people (4.6\%) from Serbia completed the questionnaire. Due to the small size of the Serbian subsample, it is not analyzed in more detail in our study, but we also take them into account when establishing global characteristics, and we also use their "good practices" to enrich and compile our best practice collection.

Table 1: Distribution of respondents $(N=463)$ by country

\begin{tabular}{l|r|r}
\hline & people & $\%$ \\
\hline Hungary & 211 & 48,3 \\
\hline Romania & 103 & 23,6 \\
\hline Slovakia & 103 & 23,6 \\
\hline Serbia & 20 & 4,6 \\
\hline All: & 437 & 100 \\
\hline
\end{tabular}

Respondents ranged in age from 21 to 70 years, with a mean age of 42.7 years $(s=9.68)$ and a median of 42 years.

The majority of respondents came from smaller settlements: village or non-major (probably smaller) city is the place of residence. 
Due to the peculiarities of the field of human services, higher education degrees dominated. In the case of men, only 2 people (without high school diploma) have a profession $(8 \%)$, in the case of women there are 3 people $(0.73 \%)$. Only one man (4\%) has a high school diploma as the highest level of education, but there are $56(13.6 \%)$ women. $88 \%$ of men (22 people) and $83.74 \%$ (345 people) have a college or university degree. Due to the small number of men surveyed (25), it is not possible to draw a valid conclusion, but a slight trend, which is common in other statistics, seems to be observed: , as if it were observable: men's educational attainment tends to focus on the "edges" (either they finish high school during graduation or go beyond high school diploma), while women more often "stop" at high school diploma.

In summary, we can state that in terms of educational qualifications, according to the main target group of the research (human service sector, professional field), high educational qualifications are typical. $370(84.7 \%)$ of the 437 respondents had at least a degree in higher education (3 of them had a doctorate) and only 7 had not completed their high school studies.

In terms of occupation, the largest subgroup belonged to teachers and trainers: pedagogical assistant (eg nurse, pedagogical assistant), early childhood educator, kindergarten teacher, teacher, university lecturer, head of some pedagogical institution, and we included those who wrote only about themselves. that a "teacher" or other special pedagogical activity has been designated (e.g., dance teacher, dormitory educator). There were also those working in the mixed field of health care and pedagogy among the respondents, e.g. special needs educators, physiotherapists.

In addition to the above 10 categories, we have classified health workers (eg doctors) and those working in the social sphere (eg family helpers) into a separate occupational group. In addition, we created 3 "other" categories, the "other leader" (eg did not indicate in which institution he / she is leading), the "other, non-PHS career" category (P: pedagogical, H: health, S: social ). This includes respondents who cannot be classified into the above groups, e.g. cleaners, chefs, administrators, among whom there may be some respondents working in human services, but the majority may not be listed here. The third group included respondents whose work could not be identified (i.e., they could work in education, health, or the social sphere - or elsewhere) but not as a leader (e.g., "employee," "Maternity leave," "intellectual work," or similar answers). Based on the above, the respondents were classified into 15 job groups, from which 12 can be clearly classified as human services:

\section{Family background of respondents}

From the point of view of our study, the extent to which respondents experience intergenerational communication in their own family is not incidental.

$12.81 \%$ of the respondents (56 people) live alone or in a relationship, so they cannot currently experience intergenerational communication and coexistence within their household. The vast majority experience a two-generation (typically parents and children) family, in some cases a singleparent family (345 people; $78.95 \%$ ), while $8.24 \%$ (36 people) live in a three-generation large family (Table 2).

Table 2: Number of generations in the household of respondents

\begin{tabular}{l|l|r}
\hline & people & $\%$ \\
\hline 1 generation & 56 & 12,81 \\
\hline 2 generations & 345 & 78,95 \\
\hline 3 generations & 36 & 8,24 \\
\hline All: & 437 & 100 \\
\hline
\end{tabular}


In terms of proportions, we found the most "one-generation families" in Hungary (16.1\%; compared to $10.7 \%$ in Slovakia and $9.7 \%$ in Romania), while most three-generation large families were among the respondents in Romania $(11.6 \%)$. ), while it was $9.7 \%$ for respondents in Slovakia and $6.2 \%$ for Hungarians.

A total of 40 families had a grandparent among the respondents (for 4 families this was not associated with a three-generation sample as they do not raise a child). Almost ten times as many families raise children: 369 out of 437 respondents (84.4\%). The number of children ranges from 1 to 6 among the respondents, with an average of 1.59 children, which roughly shows the trends in childbearing typical of the area.

\section{Roles and values}

Respondents overwhelmingly say that raising children is predominantly a joint task of mother and father (412 people; 94.3\%), while the traditional pattern ("more of a mother's job") is shared by only a few (25 people; $5.7 \%$ ). There was no respondent who thought that raising a child was fundamentally the responsibility of the father, or considered any institution more important in raising a child than the family, or perhaps thought that the child did not even need a meaningful upbringing.

Of those who the primary role of mother, 12 are educators (including leaders) and 2 are family support professionals, presumably based on the concept of primary attachment, which emphasizes the crucial importance of the mother-child relationship. The remaining 11 main areas of work are unidentifiable or not related to human services. So it seems that whether we are a human services professional or not, the majority is now in favor of a balanced role.

Examined by country, the proportions of Slovak respondents were in this position (10 people; $9.71 \%$ of Slovak respondents), in Hungary 11 people $(5.21 \%)$ agreed with this statement, while in Romania only 4 people $(3.88 \%)$. The group of those who agree is too small to make a wellfounded statement, but the differences between countries are large enough that this difference of opinion deserves further research on such a fundamental family pedagogical issue.

Question 13 examined respondents 'value preferences along five dimensions (family, workplace, friends, entertainment, sports). On a five-point scale, respondents in all categories scored between 1 and 5 in the importance of the values given in their lives (even in the family category, there were two 1 values), but the means and standard deviations show well that each category does not have the same specific gravity. in the lives of respondents.

First came the family $(\mathrm{m}=4.94, \mathrm{~s}=0.378)$, followed by the workplace $(\mathrm{m}=4.3, \mathrm{~s}=0.571)$, friends $(\mathrm{m}=4.16, \mathrm{~s}=0.694)$ and the category of leisure and entertainment $(\mathrm{m}=4.07, \mathrm{~s}=0.694)$ followed (Table 3). Respondents consider sports activities to be the least important in their lives ( $\mathrm{m}$ $=3.68, \mathrm{~s}=0.826$ ), here only 48 people marked a value of 5 (eg 419 people in the family, while 100149 people ranged those who gave a value of 5 in the work-friend-leisure triple).

Table 3: Respondents' value preferences on a five-point scale

\begin{tabular}{l|l|l|l|l|l}
\hline & family & work & friends & leisure & sport \\
\hline Mean & 4,94 & 4,3 & 4,16 & 4,07 & 3,68 \\
\hline Median & 5 & 4 & 4 & 4 & 4 \\
\hline Mode & 5 & 4 & 4 & 4 & 4 \\
\hline Deviation & 0,378 & 0,571 & 0,694 & 0,694 & 0,826 \\
\hline
\end{tabular}

Each value dimension is significantly related to each other, so whoever characterized himself with higher values in one category tended to denote 
higher scale values elsewhere, or vice versa. At the same time, the impact strength typically ranged from weak to medium categories, suggesting that respondents were still happy to differentiate between each value dimension.

However, if we approach the microstructure of families, we may come across an interesting phenomenon. Respondents 'values are not affected (!) When raising a child, however, the presence of grandparents is already an influencing factor. There is a correlation with the presence of grandparents in two groups of values, one with friends $\left(\mathrm{m}_{\text {with_grandparent }}=3.95 ; \mathrm{m}_{\text {without_grandparent }}=4.18\right)$ and the other with sport ( $\mathrm{m}_{\text {with_grandparent }}=3.40$; $\left.\mathrm{m}_{\text {without_grandparent }}=3.71\right)$. The correlation is very small but clearly significant for both friends $(\mathrm{p}=$ 0.047, $\left.\eta^{2}=0.009\right)$ and sports $\left(p=0.024, \eta^{2}=\right.$ 0.012 ). The presence of the grandparent (s) in a family can therefore restrain the importance of friendly relationships and the desire to play sports. Of course, the phenomenon may not necessarily be due to the identity of the grandparents, but also to other, unexamined factors, e.g. the presence of grandparents indicates a more difficult financial situation, which can affect the pursuit of "more money-needed" activities, and thus their importance in a person's life.

\section{Common family activities}

Common activities bring together human groups, including families. What and how often do families do together?

The most common (everyday) activities are shared conversations (366 people; 83.8\%), shared meals (302 people; 69.1\%) and electronic communication (289 people; $66.1 \%$ ) according to the modern age. More than a quarter of families also have everyday shared television (188 people, $43 \%)$ and shared learning (128 people; $29.3 \%$ ). Of course, the latter is typical of families raising children (126 out of 128 families raising children), but even in the case of families with children (377 families) it is still only $33.4 \%$.

Several times a week, co-cooking (145 people, $33.2 \%$ ) appears in his category as a "list leader", and many families remain characterized by shared television (129 people; 29.5\%) and electronic communication (100 people; $22.9 \%$ ).

If we look at activities that are at least weekly (almost every day, several times a week, every week), we can state that the vast majority of families have a common conversation (423 people, 96.8\%), electronic contact (411 people, 94\%). ) and shared meals (406 people; 92.9\%). Shared television can also be a common cohesion activity (361 people, 82.6\%), and in addition to shared cooking, cleaning, shopping and learning, the frequent presence of play is really welcome (271 people; $62 \%$ ).

The smaller importance of sport among the respondents can also be seen in the relatively lower number of joint sports activities (168 people; $38.5 \%$ ), and a Central European characteristic, compared to the Western lifestyle, is also the insignificant importance of visiting restaurants (the least joint activity on a weekly basis!) (41 people; $9.4 \%)$.

The list of non-regular joint activities ("nontypical", "occasional") also provides important lessons. The least common joint activity is attending sporting events (316 people; $72.3 \%$ ), and it is not just that sporting events take place 'occasionally', because the narrowly defined 'nontypical' category is also far from being led by this activity ( 146 people; 33.4\%). Visiting restaurants (257 people; $58.8 \%$ ) and participating in cultural programs (256 people; $58.6 \%$ ) are still not regular activities at all - although these are sometimes more common in family life than before. attendance at the aforementioned sporting events. Joint sports are also rare in 200 families (45.8\%), and here the absolutely "non-typical" category also affects 100 families $(22.9 \%)$. 
In the case of 6 respondents, the joint conversations are also omitted. None of these have a grandparent present, but four of them raise children ( 2 or 3 children). In two of the four families, the respondent was a teacher (a kindergarten teacher, a teacher). A suspected deteriorating relationship may be behind the responses. The lack of regular joint meals also affects only a small number of families (20 people; $4.6 \%$ ), 19 of the 20 families do not have grandparents, but 14 of them raise children. Thus, in the most important, "classic" family cohesion activities, the presence of grandparents seems to be a protective factor, but the presence of children is not.

Relatively few families are left behind by electronic contact (21 people; 4.8\%) and shared television (47 people; 10.7\%), but these can be easily replaced by other, sometimes more valuable programs, personal communication.

\section{Transgenerational patterns}

Four of our questions were about socialization processes, two were about what respondents learned from previous generations, and two were about reverse socialization mechanisms, what respondents passed on to their own parents, and what they themselves learned from their children.

We asked about four areas of activities learned from grandparents, parents that are closely related to the household, things to do around the house: baking, cooking; household knowledge (cleaning, washing, ironing); sewing, embroidery; gardening (Table 4).

The responses show that the main source of baking, cooking, and household knowledge in general is the generation of parents rather than grandparents. At least 8 out of 10 respondents in both categories took over the "basics" from their parents, while the effects of grandparents are typical of no more than 4 (household knowledge) -
Table 4: Taking over household knowledge from previous generations

\begin{tabular}{l|l|l|l|c}
\hline & & people & $\%$ & $\begin{array}{c}\text { difference } \\
\text { (percentage point) }\end{array}$ \\
\hline \multirow{2}{*}{ Baking, cooking } & grandbarents & 259 & 59,3 & \multirow{2}{*}{21,2} \\
\cline { 2 - 4 } & parents & 352 & 80,5 & \\
\hline \multirow{2}{*}{ Household knowledge } & grandbarents & 185 & 42,3 & \multirow{2}{*}{44,4} \\
\cline { 2 - 4 } & parents & 379 & 86,7 & \\
\hline Sewing, embroidery & grandbarents & 196 & 44,9 & \multirow{2}{*}{$-6,2$} \\
\cline { 2 - 4 } & parents & 169 & 38,7 & \multirow{2}{*}{$-2,8$} \\
\hline Gardening & grandbarents & 263 & 60,2 & \multirow{2}{*}{} \\
\cline { 2 - 4 } & parents & 251 & 57,4 & \multicolumn{2}{|c}{} \\
\hline
\end{tabular}

6 (in the case of baking, cooking) people. The more intense effects of parental effects can be seen clearly in household knowledge, with a difference of more than 44 percentage points. Presumably, this may be due to the rapid development of household technologies, with which grandparents are less able to keep up.

The effects of grandparents, only to a small extent, are stronger than the effects of parents on two activities, namely sewing, embroidery, which is a declining home activity in the modern age, and gardening.

Respondents were also able to identify four activities and knowledge materials that go beyond the household and the things around the house: love of reading, raising children, political and historical knowledge. In all areas, parental influences are stronger, although almost identical response rates have already been obtained in the transfer of historical knowledge.

Similarly to the previously mentioned household knowledge, the child rearing role of grandparents collapses to a large extent, the difference is 38.2 percentage points. This may be due in part to the fact that grandparents socialized at a very different age than the parental generation, so that "then and there" parenting methods are now less applicable. Another causal factor may be that the respondents 
themselves may have experienced less of the parenting methods in their own childhood than the family upbringing impact system provided by their parents.

Two questions in the questionnaire concerned reverse socialization mechanisms. One question was about what the respondent learned from his own children, while the other was about what he taught his own parents.

Among the knowledge learned from children, there were five predefined answers to modern technical tools (using a mobile phone; appearing on a social site (eg Facebook); using email; electronic administration (banking, mobile uploading, etc.); learning about interesting / useful websites); symbolic forms of self-expression (dressing, modern vocabulary) and political knowledge.

The above options were also included in the knowledge transfer and socialization processes manifested towards the parents of the respondents, which - due to the age characteristics - we supplemented with two more items, "baking, cooking" and "household knowledge (cleaning, washing, ironing)". In both questions for samples taken from children and for samples passed on to parents, it was possible for respondents to use the "other" category, where they could also provide other areas in text. A lot of respondents used this option.

In the case of patterns learned from children (excluding those who do not raise at least one child in their family, thus $\mathrm{N}=369$ ), the respondents marked an average of 2.28 ( $\mathrm{s}=1,520)$ answers, most $(\mathrm{N}=168)$ marked only one answer. , but the median was already at 2 . Moreover, there were those who bravely marked areas (the fact that 5 options applied to IT skills also played a role in this) and 35 people $(9.49 \%)$ gave a response number between 5 and 8 (of which 3 or 4 marked IT areas). A significant proportion of respondents thus acknowledged that they could even be the "host" in reverse socialization mechanisms. The higher the age of the respondent, the more he feels this $(\mathrm{p}=0.00 ; \mathrm{r}=0.552)$.

However, these values still lag behind the transfer of knowledge to parents, i.e., when the respondent acts as a "teacher".

The mean number of samples submitted was $2.86(\mathrm{~s}=1.463)$, the most common response rate was 2 , and the median was 3. However, the maximum number of nominations here was only 7 , but the number of those who submitted at least 5 nominations had already risen to $60(13.73 \%)$. However, the result seems more concise when we consider that two more options were already given for the role of teacher (11), although this, as we shall see, has no practical significance.

The role of "teacher" towards parents is also related to the respondent's age, however, the relationship is reversed ( $p=0.00 ; r=-340)$, as age increases, fewer and fewer respondents feel that they are transferring knowledge to their parents. There may be a number of factors in the background, ranging from progressively eroding memories of deceased parents to a more critical approach to the younger age group to age-specific features of IT knowledge.

In any case, the above results show that respondents in reverse socialization situations feel more like "teachers" than "learners". However, the differences are not necessarily strong, and many are willing to admit that they also take over elements of knowledge and behaviors from their children. It is immediately apparent from the data sets that, with one exception, there is no area that would be relevant to more than half of the families. A spectacular exception is the use of mobile phones (358 people; 81.9\%), where respondents are teachers of their own parents rather than students.

It is clear that there are "taboo areas" in which reverse socialization is not present or that respondents do not admit this for some reason. One was the use of email, for which there was no respondent who indicated that he had learned to 
use it from his children, but not even that he had been the "teacher" of his parents.

Regarding the effects on parents, the special emphasis on cooking and household was also not indicated by anyone. An obvious answer to this is that the influence of the parental generation is too strong towards "young people" and therefore reverse socialization is irrelevant. At the same time, we suspect two, mutually reinforcing factors in the background: on the one hand, the generation of (grand) parents is resistant to the effects, it is difficult to learn new dishes in the kitchen, for example, a reform kitchen solution may be too strange, unknown to them. The other is that this area is actually "taboo" for respondents: the household is an area of life in which being a "teacher" would be disrespectful to parents.

\section{Typical best practices for multigenerational programs}

In the textual answers, the respondents filled in a number of relatively well-known, frequently used (hereinafter: typical) generations. There was a number of overlaps in the programs for employees and clients (it is usually possible to organize the same program separately for employees and clients, and some of the programs can be open to both target groups at the same time), so we present the textual answers together below. The following programs, which can be called "typical", were encountered in the text responses:

Excursion somewhere and similar answers (eg "bus excursion", "employee excursion", "zoo program", "visit to the botanical garden", "hiking", "common parent-child excursions", "swimming", "family picnic"etc.).

Participation in cultural programs taking place in various external venues, in which the trinity of theater (especially children's theater performances), cinema and concerts appears. Interestingly, however, respondents do not really go to sporting events, museums, or exhibitions together, although to organize (see later), they organize such programs at their institution.

The institutions themselves organize "internal" cultural and sports programs in which several generations participate. If we do not take e.g. for the holidays (see later), there is also a very wide range of programs. On the one hand, "home versions" of the above "external" cultural programs also appear: a concert is held at the institution (or even a lighter "stage show"), a film screening ("cinema screening in the gym") appears, but dramatic activities are also present (e.g. „teachers (as amateur actors) performance "). However, the palette is already more colorful here, with sporting events (eg 'sports', 'sports competitions', 'sports events', 'sports afternoons', 'sports days', 'kindergarten olympics', 'aerobics days', 'football tournaments'), exhibitions ('exhibition ',' Christmas exhibition '). Several respondents also included the more general terms "cultural gala" (possibly "Gala show", "Advent gala"), "cultural events".

A very serious slice of the answers is the holding of various bolidays and celebrations within the institution, sometimes combined with participation in external programs. Most of the named festive activities are related to church holidays. Programs around Christmas (typically "Advent candle lighting", concert, "Advent evening", "Advent playhouse", fair) and programs related to egg painting at Easter are especially popular. But Pentecost ("Easter, Pentecostal life images") or the Orthodox Djurdjevdan also appeared.

Respondents also listed a number of holidays that, although of church origin or related to the ecclesiastical celebration, have become highly secularized to this day. Santa Claus is also very popular, also referred to as Santa in the former socialist countries (several have written it as "Santa's Waiting"). A special program related to 
this was "Santa Claus Train" in the responses. As with Santa, carnival was common in the responses, which was sometimes referred to by respondents by other names at times, because we could come across terms like "mask ball" or "masquerade ball". The Michael's Day Fair, Martin's Day, are also popular, and Andrew Day's Fair was also included in one answer. These answers already lead us to the famous days found in folk tradition, detached from church holidays. Here, the activities of the spring festival, May programmes (there were those who also wrote the May Tree creation), and the June programs are the most popular. Some of the responses included both fall and winter: "November Goose Days with Wine Baptism," Luca's Day, and the most popular in this category were harvest entertainments. Several referred to similar programs without giving specifics: "traditional programs", "People's Cavalcade", "autumn cavalcade". Only Halloween appeared in the answers of the Anglo-Saxon traditions, and one of its elements, pumpkin carving, was mentioned several times in the answers as an now independent, glocalized, popular activity (eg "pumpkin carving party", "Pumpkin day", "pumpkin lantern making", "Pumpkin Carving", "Pumpkin Festival", "Pumpkin Party", "Campfire with Pumpkin Carving", "Autumn Pumpkin Carver Gathering"').

Non-secular international holidays, world days and famous days also appeared in the answers. The most significant were Mother's Day, Women's Day and Children's Day, and one of the answers included Earth Day (a Slovak kindergarten teacher highlighted this separately) and Poetry Day (written by a lady working in a senior position in Hungary). One of the easier options in response to a Slovak rapporteur was the New Year's Eve ("New Year's Eve") as a workplace program that brought generations together.

While local holidays (village day, city day) appeared several times, national holidays were almost completely absent from the responses. Each time we could only read a remote reference to them, for example "Anniversaries", "historical commemorations" and once "March 15".

From the responses, it appears that celebrations linked to church and deeper-rooted (folk) traditions are the ones where most opportunities are discovered to organize intergenerational programs in the workplaces, which can be linked to classic, family roles. (Mother's Day, Children's day, Women's Day). At national holidays, however, they do not see the possibility of "familyization" in the workplace.

However, in addition to opportunities for celebration at the societal level, institutions also find a number of internal, locally-based, celebratory-type opportunities to organize intergenerational programs (local celebrations). Some of these are actually called "days": "Senior Day", "Retirement Day", "Grandma’s Day", "Craft Day", "Elves Days", "Apple Day", "Company Day", "Kindergarten Day," "Crop Day". "Children's Festival" and "local fairs" were also present in the responses. It is clear from the responses that not only two (parents, children) but also several generations are considered in some of the workplaces, which is also supported by responses such as "retirement evening", "inviting the retired" or "Greeting grandparents". But the farewells and anniversaries also focus on the older, even grandparent generation. In many cases, the institutions also organize more universal "family days" as running, jogging programs.

There are also personal festive occasions in the line of holidays, which in each case can become programs that bring together several generations: "common birthday", "name days", but we may even come across the answer "weddings". Celebrating birthdays, name days at work, and related greetings are well-known festive activities, but in formal venues they rarely expand into a multi-generational program. 
The two central elements of lighter, intergenerational programs are eating / cooking and dancing. Among these, the following programs are typically popular: "cooking" / "family cooking" / "cooking together", "bacon frying", "goulash competition" / "goulash cooking", but there are "venison cooking competitions", or in two cases making gingerbread and honey cookies, and the common "ice cream eating" also appeared. In connection with eating / cooking, it was stated in several responses that this program is also interpreted as a kind of gastronomic competition, organized by the institutions. Among the dance entertainments, the various balls (charity; parents; carnival; even brigade ball) were the most frequently mentioned in the answers, but the dance house and the "retro-disco" are not unknown either (indeed, the disco era belongs to the experience world of parents or younger grandparents today). A Wreath Program for children's dance performances was also included in the responses. And perhaps the answer "School party" can be classified as "eater-dancer", maybe also "PJ party" (written by a Romanian kindergarten teacher). Interestingly, folk dance appeared in only one response specifically, with the title "Folk Dance Festival" (of course, the former "dance house" can also mean folk dance content). Perhaps this would suggest that the "rise of folk dances" of recent decades might be declining, or that age group breakdowns are more strongly present in these programs?

We have seen that gastronomic programs sometimes go through competition. Competitions and quizzes have appeared in many answers, so it can be a popular form of various intergenerational content. Among the competition programs, sports competitions dominate (in some more special cases we return to atypical forms), from the quizzes, "Who knows what?", "Talent shows" were named and storytelling. Storytelling as content was already included in several responses, e.g. also in the form of a storyteller hut. It seems that "tale" as an ancient genre has still not disappeared from the toolbox of community building.

In the answers, we could find several programs that are more closely related to one type of institution or maintainer. In church-maintained institutions, common (multi-generational) sacral activities are more common (but not only there): worship (even in ecumenical form: "graduation in kindergarten, graduation in school, combined with closing and opening school ecumenical worship in the Reformed and Catholic alternately in church "), in the form of Bible lessons, spiritual practice, or a blessing (e.g., blessing of a crop, blessing of an Advent wreath). The answers show that the programs typically related to educational institutions (nursery, kindergarten, school) are also excellent for moving several generations: year openers and yearends, open days, school information days (eg "school tasting"), school visits, enrollment programs, "professions night" and other" learningrelated programs '. Among the easier, more playful options appeared: camps, summer daytime programs, play afternoons, nursery tasting, babymum club. Craft afternoons and classes, creative workshops, "creative, DIY afternoon" and playhouse programs can often be found in the answers, but these can also be more independent opportunities from educational institutions.

Professional, educational programs for adults can also address several generations. Based on the answers, these can be divided into three main types: lectures (eg "Lectures on health.", "Lectures on family visits"), workshops (eg "Workshops, Seminars - on the subject of family education", discussions (with teachers, psychologists) about the family, children "), further trainings, including trainings (" Team Building Day "). It is likely that the answer "Parents' School ", which is not explained in more detail, can also be placed in the three categories listed above. The institutions organize professional 
programs in the main field of health, in which children can be well involved: "health afternoon", "health day", "health week", "Movement and health education.". Of course, it is possible to plan "days" or "weeks" on other topics, but we did not get too much support for these from the answers, they were referred to as thematic days or projects, project closing events by the respondents.

Volunteering is not typical of our region, this was also reflected in the responses. Two referred to such activities, but they were also limited to outdoor activities: "Common yard care," "Common yard arrangement, flower planting". Also, two respondents appeared to have common conversations, which - presumably - are not formally organized by the institutions, but may be suitable for building intergenerational relationships.

\section{Atypical best practices in multigenerational programs}

In about $10 \%$ of the responses (27 respondents [9.71\%] organized programs for employees, 33 respondents [11.34\%] organized programs for clients), we encountered elements that were less known or novel in their entirety or in some details. , they seemed more unusual (hereinafter referred to as "atypical" programs). Of course, the typical atypical classification in many cases means a subjective, intuitive classification, but it can support the daily program organizing practice well, so we use it in our present study as well.

There were ten respondents who gave atypical answers in both categories (programs organized for employees - clients). 6 of them were respondents from Hungary and 4 from Slovakia, none from Romania or Serbia. 2 of the 10 respondents, were kindergarten teachers and 2 were teachers working in schools and 1 could not be identified as a "teacher"; 5 respondents came from other areas (eg nurse, family helper). Among the 10 institutions we find state, local government and non-governmental organization maintained institutions as well, but there was no church maintained among them.

In the following, in part following the categories identified for typical responses, we review the lessons learned elements of atypical responses.

Among the excursions, as well as the programs taking place in external locations, we could find some exciting, - now - seemingly unusual possibilities: a factory visit, a "visit to a sister village", a "visit to agricultural lands". In addition, the responses included a recommendation for city programs for families and a further reflection on a traditional type of program: "We usually organize a zoo trip for families in need, with the help of a sponsor." Product demonstrations, as intergenerational programs, can take place in external as well as internal venues, so there are even opportunities to fall into this category ("external venues programs").

The issue of "family" also appears directly in many institutions (as we have seen in typical responses, eg in the form of family afternoons), and can even encourage staff to take more innovative solutions. Programs specifically targeted at families include "Grandma's Afternoons", "MomDad Come Play with Us", "Family Saturday", but the company day has also appeared as a family program ("Family Company Day"). \&quot;Sleeping in the workplace\&quot; can also be a great intergenerational program, as stated by a Hungarian Customer Support Administrator. Among the services targeted at families, we also found a well-known but less exploited opportunity in our area for workplace childcare workers ("Previously, during summer holidays, children could come into the workplace so their supervision was resolved while the parent worked while the children played.").

Many local cultural programs also provide opportunities to bring generations together. These include book presentations, a fairy tale festival, a "grandma's story" program, and other "shared storytelling" occasions ("fairy tale" has appeared 
more than once in typical forms as content that brings generations together!). The various programs and presentations can also be explicitly interactive ("Interactive programs, presentations").

The various festive occasions also appear strongly in the atypical responses. Some of these have appeared in our region in recent decades and have not yet become a well-known, widely followed tradition. The best known (also appeared in 9 responses) is Father's Day, which seems to be becoming an increasingly popular event; this day was probably also thought of by the respondent who wrote about "men's day," although this could also mean an employee program corresponding to some kind of women's day. The responses also included World Breastfeeding Day and Europe Day. Several also wrote about "Roma Day", which may be related to the International Roma Day, but respondents may have thought of some other day showcasing Roma culture. Among the local festive occasions, the "Shepherd's Meeting" and the "Youday" programs of the University of Debrecen can be classified as less common "fiesta-like" intergenerational programs, although it would be relatively easy to invent and implement new, breakthrough solutions in this area.

We could not encounter dance programs in the atypical responses, however, "occasions related to shared meals" were eagerly thought of further in the workplaces of the respondents. Nowadays, pig slaughtering is no longer typical for a staff, but examining the answers is not unknown either. At the same time, not only traditional food can bring people of different ages together, but even a "reform cooking competition". In addition, both "Baking at the Retirement Club" or "Catering the Retired" are good options.

In addition to the traditional sports programs discussed earlier (sports day, football tournament, etc.), the events that move the physique include "Running together" and "walks", as well as the "walks in nature" programs (in sport programmes " coach driving " appeared, but its form was not clear from the answer [eg. as a spectator at an external program]). Health preservation programs include heath screening at the workplace not only for employees but also for clients. The "relaxation plan" (written by the deputy director of a Slovak pedagogical institution) serves to preserve mental bealth, and there are places where psychological or educational counseling awaits the representatives of different generations.

We were also able to find more innovative solutions among professional, educational programs, such as "ECO Day", "Talent Day", "Learning Festival", and "Researchers' Night". Crafts were discovered in an atypical response, the "Flower Arrangement Days, Flower Arrangement Competition".

Institutional presentation can also be a great field for intergenerational programs, which can be implemented in new forms. A simple open day can cover a longer period of time ("open days", "job tasting camp for primary school students with the help of parents"), but it can also be expanded in content to make the traditional open day richer or more specific "Open Day" or open program (e.g. "open pre-school programs"), even organized around a thematic program ("Insurance open days ”). The work in the institution can be well demonstrated with the help of exam presentations ("End of year exam presentations"), which can be included not only in the traditional "arsenal" of music schools, but also in other institutions and fields (eg a folk dance teacher wrote the answer to the quoted exam presentations ).

There are also multi-generational groups, communities or trainings organized around a specific theme that cannot be said to be typical. Such groups include the alumni community, the circle of amateur actors, the poetry circle, or the cooking club. Among the trainings, language learning in the form of online can bring several generations 
together (even if only in the online space), and the answers included ski course as well.

In some responses, in addition to the aforementioned ECO Day, an ecological approach emerged, either in combination with volunteering: "gardening", "garbage collection in a forest or meadow", and various "working afternoons" (even in connection with other events such as Advent), which also hold the potential for social work for the institution. A Romanian office worker also wrote "nature conservation movements" that appear in his workplace.

At times, direct assistance to others appeared as a program that brought generations together. This is mostly in the form of some kind of donation, package distribution, and is typically related to Christmas, such as a "Christmas charity action". One answer also included, without further explanation, "Women's Protection" (the respondent was a Hungarian nurse).

\section{Summary}

Reviewing typical and atypical intergenerational programs, we were able to identify 18 categories into which intergenerational programs can be classified (each category has a number of specific possibilities). These are summarized in the following overview Table 5 .

On the one hand, the collection and dissemination of good intergenerational practices can be useful for any institution or organization that organizes programs. Even this overview, which can be considered sketchy due to its size, contains a lot of ideas and practical solutions from which you can take ideas.

On the other hand, the collection also highlights the shortcomings of the four countries examined in related areas: one third of the institutions do not pay attention to the organization of multigenerational programs or in several areas (eg volunteering, modern speacial days, supporting regular club occasions) the institutional supply palette can be further enriched and modernized.

Table 5: Main categories of intergenerational programs organized for clients and employees

\begin{tabular}{|l|}
\hline Trip \\
\hline $\begin{array}{l}\text { Participation in cultural programs at external } \\
\text { locations }\end{array}$ \\
\hline Cultural programs within the institution \\
\hline Sports programs within the institution \\
\hline Holidays, celebrations \\
\hline Institutional celebrations \\
\hline Programs related to eating and cooking \\
\hline Dance programs \\
\hline Competitions, quizzes \\
\hline Common sacred activities \\
\hline $\begin{array}{l}\text { Special programs and services of educational } \\
\text { institutions (eg open days, camps) }\end{array}$ \\
\hline Creative occasions (eg craft afternoons) \\
\hline Professional lectures, educational programs \\
\hline Consulting \\
\hline Trainings (also online) \\
\hline Clubs, "circles" \\
\hline Health screenings \\
\hline Volunteering \\
\hline
\end{tabular}

\section{References}

Bakonyi Anna, Karczewicz Ágnes (2016): Az óvodapedagógusok nagykönyve. Neteducatio, Budapest.

Korintus Mihályné,Villányi Györgyné, Mátay Katalin, Badics Tiborné (2004): Gyermekeink. gondozása és nevelése. Corvinus Kiadó, Budapest.

Rákó Erzsébet (2014). Egy hátránykezelő óvodai program tapasztalatai [Experiences of a kindergarten programme addressing disadvantage]. Szociálpedagógia [Social Pedagogy], 1(2), 5-10.

Török Balázs (2005). Óvodák és szülők. Educatio, 2005/4. 788. 
Varga Nagy, A.nikó \& Molnár, Balázs (2019). Nevelési mintázatok roma családok körében [Patterns of care in Roma families]. In Biczó, G. (ed) Így Kutatunk Mi [This Is How We Research] (ed.).
Varga Nagy, A. (2017; 2018; 2019; 2020). Családi nevelés 2. 3. [Family Pedagogy 2. 3.] (ed.). Didakt, Debrecen. 